\title{
Peculiarities of carrying capacity evaluations of cylindrical CFST columns with new type casing
}

\author{
Olena Sinkovskaya ${ }^{1 *}$, and Andrey Ignatenko ${ }^{1}$ \\ ${ }^{1}$ Kharkov National Automobile and Highway University, Department of bridges, constructions and \\ building mechanics Yaroslava Mudrogo st. 25, 61002 Kharkov, Ukraine, Kharkov
}

\begin{abstract}
This paper deals with a cylindrical steel-concrete load-bearing unit. The feature of the unit is a steel mesh casing that is made from the expanded metal mesh. The optimal parameters of the suggested footing are determined taking into account anisotropy, i. e. different strength and rigidity in different directions that coincide and do not coincide with the direction of reinforcement. The optimal cell angle, when a casing deformation brings about maximum compression of a concrete core, is determined. Details for theoretical calculation of the bearing capacity of a cylindrical steel-concrete load-bearing unit are provided taking into consideration a complex threedimensional structure of the suggested mesh casing. The validity of the calculations is confirmed by comparison them with the results of the Lira software package. The results of the calculations are provided in the form of the table showing the dependence of the adduced thickness of the plate on the longitudinal movement of the strip of the steel mesh casing. The dependencies to determine the adduced thickness of the mesh casing using the graphical method are provided for all the existing types of the mesh using concrete wedges or excluding them.
\end{abstract}

\section{Introduction}

The constructive decision of the intermediate column supports of a bridge has several routine solutions $[1,2]$ where reinforced concrete has been used for many years. However, it is only lately that steel-concrete bearing units have been used to build the footing of buildings and structures. The category of steel-concrete units includes tube-concrete ones as well as various systems with confinement-shear reinforcement in the form of radial rings, hoops, clamps, spiral windings etc. This category of the steel-concrete load-bearing units of the footing also includes the elements whose casing is made with a mesh [3] - a mesh casing. It differs from traditional solutions in the way that the casing is made from a mesh rather than a solid plate (Fig. 1).

The expanded metal mesh is a metal plate having a grooved surface with uniformly spaced cells. It has a number of advantages $[4,5]$.

The features and advantages of the operation of a mesh casing, as well as research by V.S. Shmukler [5, 6], substantiate the theoretical research into cylindrical steel-concrete structures having a mesh case where cells are distributed both along and across the generatrix.

\footnotetext{
* Corresponding author: iglema@meta.ua
} 

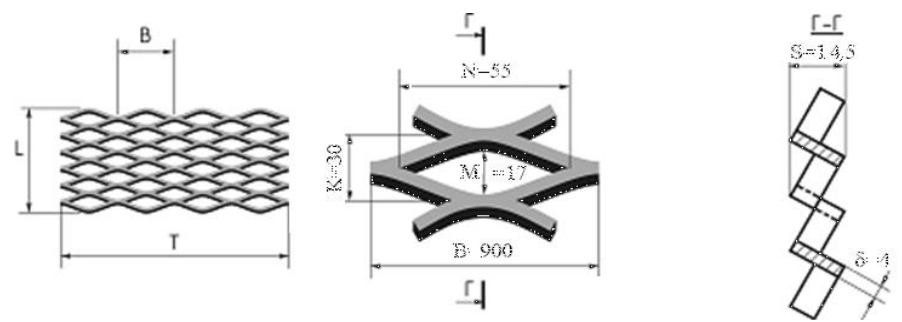

Fig. 1. Main geometric characteristics of the expanded metal mesh.

\section{Objectives and tasks}

The aim of this theoretical research is to investigate the features of the steel casing of a new type of cylindrical steel-concrete load-bearing units in the footing of buildings and structures. The tasks of this research are to choose the optimal parameters of the expanded metal mesh for the rational functioning of the steel-concrete structure having the mesh casing as well as to develop the method of the determination of the reduced thickness of the steel casing of a new type.

\section{Determination of optimal parameters of the casing of a new type}

The proposed casing of a new type is a composite where reinforcement is made from the expanded metal mesh (Fig. 2), which is made from a solid steel plate as a workpiece.

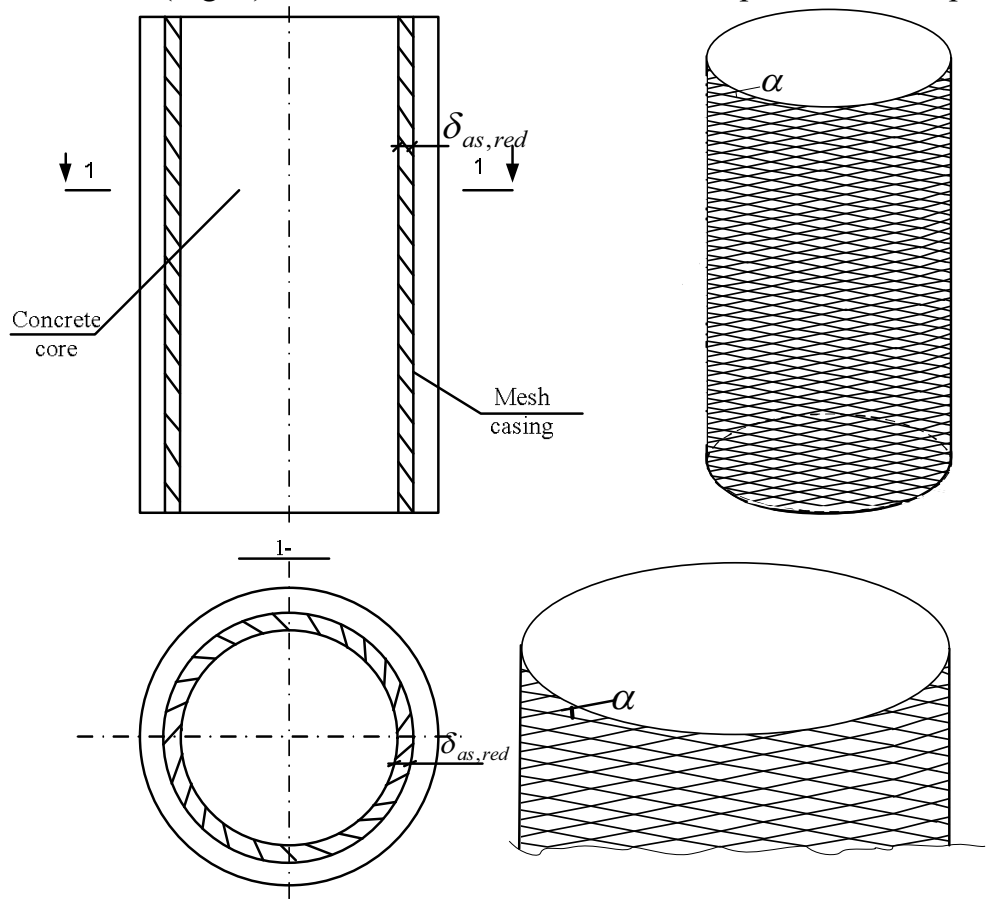

Fig. 2. Determination of an optimal angle for the direction of the mesh casing cells relative to the generatrix of a structure.

The feature of this material is anisotropy, i.e. different strength and rigidity in various directions that coincide and do not coincide with the direction of reinforcement [7]. It 
dramatically differs from superficially similar structures that have been researched by V. V. Vasiliev, V.L. Biderman, V.Eh. Vildeman, A. N. Elpatevskii, M. S. Saiidi, Y. C. Ou, Z. C. Girgin et al. These structures are made by means of layer-by-layer steel wire winding in the form of a net or spiral. Therefore, when forming the model, the vector parameters of expanded metal mesh are as follows:

$$
\{\bar{x}\}^{T}=\left\{\alpha, R_{r}, \delta, S, B, M, N, K, G\right\},
$$

where $\alpha$ - is the inclination angle between the generatrixes of the cells of expanded metal mesh; $R_{r}$ - the mean radius of the casing of a new type; $\delta$ - the thickness of a workpiece plate; $S$ - the overall thickness of a plate; $B$ - cell spacing used for height; $M$ - cell width; $N$ - cell height; $K$ - cell spacing used for width; $G$ - the width of cell feeding (GOST 8708-06).

The most representative parameter that integrates all the parameters is the inclination angle of expanded metal mesh cells. Therefore, taking into account the complex structure of the mesh casing of a cylindrical steel-concrete load-bearing unit, first of all, the optimum inclination angle of cells must be determined when the deformation of the casing brings about the maximum compression of a concrete core [8]. Depending on angle $\alpha$, three types of deformation [9] of a cylindrical steel-concrete load-carrying unit can take place in the course of loading (Fig. 3). Figure 3 shows that the second type of deformation is the most optimum to gain maximum compression by the casing of a new type (Fig. $3 \mathrm{~b}$ ).

a)

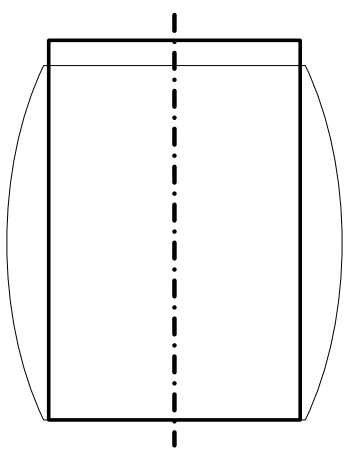

b)

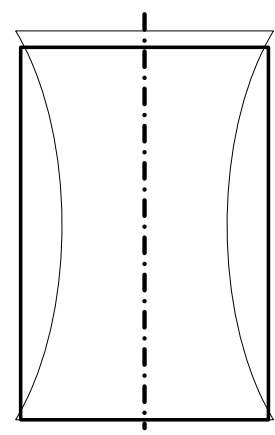

c)

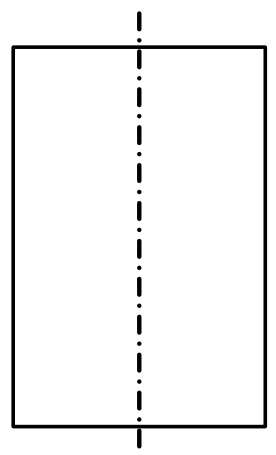

Fig. 3. The scheme of the deformation of the casing: $a$ - the first type of deformation; $b \dot{-}$ the second type of deformation; $\mathrm{c}$ - the third type of deformation.

Table 1. Determination of inclination angles of cells of expanded metal mesh.

\begin{tabular}{|c|c|c|c|c|c|c|c|}
\hline 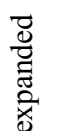 & 言 & छ & $\begin{array}{l}\Xi \\
\vdots \\
\infty\end{array}$ & 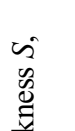 & $\begin{array}{l}\text { Dimension of } \\
\text { cell aperture } \\
\quad M \times N\end{array}$ & $\alpha=2 \operatorname{arctg} \frac{M}{N}$ & $\begin{array}{l}\gamma=(180-\alpha)^{\circ}= \\
=2 \operatorname{arctg} \frac{N}{M}\end{array}$ \\
\hline 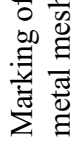 & 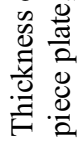 & 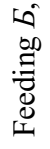 & 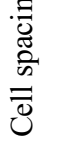 & 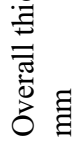 & & & \\
\hline 406 & 4 & 6 & 90 & 12.7 & $17 \times 53$ & $34^{\circ} 21^{\prime}$ & $145^{\circ} 39^{\prime}$ \\
\hline 506 & 5 & 6 & 110 & 13.0 & $23 \times 58$ & $43^{\circ} 15^{\prime}$ & $136^{\circ} 44^{\prime}$ \\
\hline 508 & 5 & 8 & 110 & 16.8 & $20 \times 50$ & $43^{\circ} 36^{\prime}$ & $136^{\circ} 24^{\prime}$ \\
\hline 510 & 5 & 10 & 110 & 20.5 & $16 \times 67$ & $26^{\circ} 51^{\prime}$ & $153^{\circ} 08^{\prime}$ \\
\hline 606 & 6 & 6 & 125 & 13.4 & $17 \times 64$ & $29^{\circ} 45^{\prime}$ & $150^{\circ} 15^{\prime}$ \\
\hline 608 & 6 & 8 & 125 & 17.1 & $25 \times 70$ & $39^{\circ} 18^{\prime}$ & $140^{\circ} 41^{\prime}$ \\
\hline 610 & 6 & 10 & 125 & 20.8 & $15 \times 64$ & $26^{\circ} 23^{\prime}$ & $153^{\circ} 37^{\prime}$ \\
\hline
\end{tabular}


So, under the inclination angle of cells $\alpha=2 \beta<70^{\circ} 32^{\prime}$, the second type of deformation, which predetermines the horizontal orientation of cells, is rational for the compression of the concrete core.

The results of various inclination angles of cells in longitudinal and lateral directions for expanded metal mesh are in table 1. They are available in GOST [3].

Table 1 shows that an optimum direction for the maximum compression of the concrete core of the mesh casing is the direction of cells across the generatrix of a cylindrical steelconcrete load-carrying unit. As a result, this direction of cells relative to the generatrix of the structure is used by default during further theoretical research.

\section{Methodology of the determination of the reduced thickness of the new type casing of cylindrical steel-concrete load-bearing units in the footing of buildings and structures}

The current methods to calculate the load bearing capacity of a cylindrical steel concrete unit take into account the thickness of the steel casing. This fact considerably complicates the determination of the bearing capacity of the steel-concrete unit of a new type, which has the mesh casing. In view of it, we have developed several methods to determine the reduced thickness of the mesh casing. It enables us to verify their validity and representativeness.

Theoretical calculations are made using the superposition principle, i. e. the load bearing capacity of a concrete core and steel casing are considered as two independent components, which operate independently without any cooperation. In that case, to take into account the increase of the bearing capacity due to the compression of the concrete core by the casing, we can accept some points:

- massive (inflexible) structures are considered;

- the concrete core, which is encased in the steel casing, experiences a volumetric stressed state, i.e. triaxial compression. Radial stresses in the concrete core are equal to stresses in the places of contact between the casing and concrete core under the impact of the axial compression force;

- maximum hoop tension stress in the steel casing does not exceed the characteristic value of steel strength on the tensile yield limit;

- the value of the contact stress of the steel casing is equal to the value of the lateral resistance of the steel casing and the radial deformations of the concrete core resulting from the axial compression force; it depends on the ratio of the casing wall thickness $(\delta)$ to the mean radius of the steel-concrete unit $\left(R_{r}\right)$;

- the value of the contact stress of the casing also depends on the reinforcement ratio of the lateral section of the steel-concrete load-bearing unit.

The geometric characteristics of the lateral section of the cylindrical steel-concrete loadbearing unit are determined, taking into consideration the features of the lateral section of the new type casing that contains the actual area of the steel mesh casing as well as concrete wedges, which fill the cells of the mesh casing.

The actual area of the cylindrical mesh casing is calculated as the product of the real perimeter of the steel mesh casing, taking into account the void of cells, and the thickness of the workpiece plate:

$$
A_{a s}^{\text {actual }}=S_{a s} \cdot \delta_{z}=\pi \cdot k \cdot \delta_{z}\left(D_{o u}-\delta_{a s}\right),
$$

where $S_{a s}$ is the perimeter of the cylindrical mesh casing; $\delta_{z}-$ the thickness of the workpiece plate of the steel mesh casing; $\delta_{a s}$ - the thickness of the mesh casing that is equal to the overall thickness of the mesh $(S)$, according to GOST [3]; $D_{o u}$ - the outer diameter of the steel mesh casing of a steel-concrete load-bearing unit; $K$ - a coefficient, 
taking into account the geometric dimensions of mesh cells (Fig. 1), namely, $G$ - feeding width, $B$ - cell spacing used for height, $A$ - an elongation dimension after every stroke of the press [3], which can be calculated as follows:

$$
k=\frac{M}{K}=\frac{N}{B}
$$

So the structure under review is a composite that has both the expanded metal mesh to reinforce the unit and concrete, which fills the cells void of the expanded metal mesh to bind material. During the calculation of the bearing capacity of the cylindrical steelconcrete load-bearing unit, the mass concrete in the form of wedges is included into the section of the mesh casing by means of the reduction of the area of concrete wedges to the steel area, using the equation:

$$
A_{c, \text { red }}=\frac{A_{a, k} \cdot E_{c}}{E_{a}}
$$

where $E_{a}, E_{c}$ are the deformation modules of the $1^{\text {st }}$ type of metal and concrete correspondingly; $A_{a, k}$ is the area of the concrete wedges of the mesh casing, which is calculated as follows:

$$
A_{c, k}=A_{a s}-A_{a s}^{\text {actual }},
$$

where $A_{a s}$ is the initial area of the lateral section of the mesh casing, which has the thickness of $\delta_{a s}$, nonregistering the complex structure of the mesh casing. It is as follows:

$$
A_{a s}=\frac{\pi \cdot D_{\mathrm{H}}^{2}}{4}-\frac{\pi \cdot\left(D_{\mathrm{H}}-\delta_{a s}\right)}{2}=\pi \cdot \delta_{a s}\left(D_{\mathrm{H}}-\delta_{a s}\right) .
$$

Then, formula 2 looks as follows:

$$
\begin{aligned}
A_{c, r e d}= & \frac{E_{c}}{E_{a}}\left[\pi \cdot \delta_{a s}\left(D_{\mathrm{H}}-\delta_{a s}\right)-\pi \cdot k \cdot \delta_{a s}\left(D_{\mathrm{H}}-\delta_{a s}\right)\right]= \\
= & \frac{\pi \cdot E_{c}}{E_{a}}\left(D_{\mathrm{H}}-\delta_{a s}\right)\left[\delta_{a s}-k \cdot \delta_{z}\right] .
\end{aligned}
$$

Hence the mesh casing cross-section reduced area $A_{\text {as,reed }}$, taking into consideration the concrete wedges reduced cross-section, is as follows:

$$
\begin{aligned}
A_{a s, r e d}=A_{c, r e d} & +A_{a s}^{a c t u a l}=\pi \cdot\left(D_{\mathrm{H}}-\delta_{a s}\right)\left[\frac{E_{c}}{E_{a}}\left(\delta_{a s}-k \cdot \delta_{z}\right)+k \cdot \delta_{z}\right]= \\
& =\pi \cdot\left(D_{\mathrm{H}}-\delta_{a s}\right)\left[\frac{E_{c}}{E_{a}} \delta_{a s}+k \cdot \delta_{z}\left(1-\frac{E_{c}}{E_{a}}\right)\right]
\end{aligned}
$$

At the same time, concrete wedges, in addition to partly performing the function of the casing, due to their integrity with the concrete core, make a natural bond between the concrete core and the steel casing. As a result, it ensures the combined action of the constituents of the steel-concrete unit of a new type.

Taking into consideration the above-mentioned transformations, the reduced thickness of the mesh casing $\delta_{\text {as,red }}$ is determined:

$$
\delta_{a s, \text { red }}=\frac{A_{a s, r e d}}{S_{a s}}=\frac{\pi \cdot\left(D_{\mathrm{H}}-\delta_{a s}\right)}{\pi \cdot\left(D_{\mathrm{H}}-\delta_{a s}\right)}\left[\frac{E_{c}}{E_{a}} \delta_{a s}+k \cdot \delta_{z}\left(1-\frac{E_{C}}{E_{a}}\right)\right]=
$$




$$
=\left[\frac{E_{c}}{E_{a}} \delta_{a s}+k \cdot \delta_{z}\left(1-\frac{E_{c}}{E_{a}}\right)\right]
$$

To test formula 8, a number of the problems to determine the reduced thickness of the new type casing are solved. The problems use various types of the concrete and the parameters of the expanded metal mesh (Fig. 1). Computing is made by the Lira software package.

Table 2. Results of the computation of the reduced thickness of the new type casing.

\begin{tabular}{|c|c|c|c|c|c|c|c|c|}
\hline \multirow{2}{*}{$\begin{array}{l}\text { Grade } \\
\text { of } \\
\text { PVL }\end{array}$} & \multirow{2}{*}{$\begin{array}{c}\text { Computation } \\
\text { method }\end{array}$} & $\begin{array}{l}\text { Type of } \\
\text { concrete }\end{array}$ & $\mathrm{C} 12 / 15$ & $\mathrm{C} 16 / 20$ & $\mathrm{C} 20 / 25$ & $\mathrm{C} 25 / 30$ & $\mathrm{C} 30 / 35$ & $\mathrm{C} 32 / 40$ \\
\hline & & $E_{c}\left(10^{4}\right), M P$ & 2.3 & 2.7 & 3.0 & 3.25 & 3.45 & 3.6 \\
\hline \multirow[t]{5}{*}{406} & \multirow[t]{2}{*}{ formula 8} & $\delta_{a s, r e d}, \mathrm{~mm}$ & 2.85 & 3.06 & 3.22 & 3.35 & 3.46 & 3.54 \\
\hline & & $\varepsilon, \mathrm{mm}$ & 0.0571 & 0.0535 & 0.0508 & 0.0487 & 0.0473 & 0.0462 \\
\hline & \multirow{2}{*}{$\begin{array}{c}\text { software } \\
\text { package Lira }\end{array}$} & $\delta_{a s, \text { red }}, \mathrm{mm}$ & 2.91 & 3.02 & 3.09 & 3.15 & 3.21 & 3.26 \\
\hline & & $\varepsilon, \mathrm{mm}$ & 0.056 & 0.0542 & 0.0529 & 0.052 & 0.0509 & 0.0504 \\
\hline & \multicolumn{2}{|c|}{ discrepancy, \% } & 2.1 & 1.32 & 4.21 & 6.35 & 7.69 & 8.6 \\
\hline \multirow[t]{5}{*}{506} & \multirow[t]{2}{*}{ formula 8} & $\delta_{\text {as,red }}, \mathrm{mm}$ & 3.54 & 3.72 & 3.87 & 4.00 & 4.10 & 4.18 \\
\hline & & $\varepsilon, \mathrm{mm}$ & 0.0462 & 0.044 & 0.0423 & 0.041 & 0.0401 & 0.0393 \\
\hline & \multirow{2}{*}{$\begin{array}{c}\text { software } \\
\text { package Lira }\end{array}$} & $\delta_{a s, \text { red }}, \mathrm{mm}$ & 3.44 & 3.6 & 3.74 & 3.84 & 3.93 & 4.0 \\
\hline & & $\varepsilon, \mathrm{mm}$ & 0.0475 & $0, .454$ & 0.0439 & 0.0426 & 0.0417 & 0.0411 \\
\hline & \multicolumn{2}{|c|}{ discrepancy, \% } & 2.91 & 3.33 & 3.48 & 4.17 & 4.33 & 4.5 \\
\hline \multirow[t]{5}{*}{508} & \multirow[t]{2}{*}{ formula 8} & $\delta_{a s, \text { red }}, \mathrm{mm}$ & 4.27 & 4.53 & 4.74 & 4.90 & 5.04 & 5.14 \\
\hline & & $\varepsilon, \mathrm{mm}$ & 0.0385 & 0.0361 & 0.0347 & 0.0334 & 0.0325 & 0.0319 \\
\hline & \multirow{2}{*}{$\begin{array}{c}\text { software } \\
\text { package Lira }\end{array}$} & $\delta_{a s, \text { red }}, \mathrm{mm}$ & 4.34 & 4.48 & 4.58 & 4.68 & 4.74 & 4.78 \\
\hline & & $\varepsilon, \mathrm{mm}$ & 0.0379 & 0.0366 & 0.0358 & 0.0351 & 0.0346 & 0.0343 \\
\hline & \multicolumn{2}{|c|}{ discrepancy, \% } & 1.64 & 1.23 & 3.41 & 4.7 & 6.27 & 7.53 \\
\hline \multirow[t]{5}{*}{510} & \multirow[t]{2}{*}{ formula 8} & $\delta_{\text {as,red }}, \mathrm{mm}$ & 4.22 & 4.34 & 4.6 & 4.82 & 5.00 & 5.13 \\
\hline & & $\varepsilon, \mathrm{mm}$ & 0.03901 & 0.0379 & 0.0357 & 0.0340 & 0.0327 & 0.0319 \\
\hline & \multirow{2}{*}{$\begin{array}{c}\text { software } \\
\text { package Lira }\end{array}$} & $\delta_{\text {as,red }}, \mathrm{mm}$ & 4.59 & 4.66 & 4.70 & 4.73 & 4.76 & 4.78 \\
\hline & & $\varepsilon, \mathrm{mm}$ & 0.0357 & 0.0352 & 0.0349 & 0.0347 & 0.0345 & 0.0343 \\
\hline & \multicolumn{2}{|c|}{ discrepancy, \% } & 8.78 & 7.5 & 2.17 & 1.9 & 5.0 & 7.32 \\
\hline \multirow[t]{5}{*}{606} & \multirow[t]{2}{*}{ formula 8} & $\delta_{a s, \text { red }}, \mathrm{mm}$ & 4.08 & 4.27 & 4.42 & 4.55 & 4.65 & 4.72 \\
\hline & & $\varepsilon, \mathrm{mm}$ & 0.0403 & 0.0385 & 0.0371 & 0.0360 & 0.0353 & 0.0347 \\
\hline & \multirow{2}{*}{\begin{tabular}{|c|} 
software \\
package Lira
\end{tabular}} & $\delta_{a s, r e d}, \mathrm{~mm}$ & 3.9 & 4.01 & 4.10 & 4.16 & 4.23 & 4.26 \\
\hline & & $\varepsilon, \mathrm{mm}$ & 0.042 & 0.0409 & 0.0401 & 0.0395 & 0.0389 & 0.0386 \\
\hline & \multicolumn{2}{|c|}{ discrepancy, \% } & 4.62 & 6.56 & 7.9 & 9.35 & 9.88 & 10.87 \\
\hline \multirow[t]{5}{*}{608} & \multirow[t]{2}{*}{ formula 8} & $\delta_{a s, \text { red }}, \mathrm{mm}$ & 4.22 & 4.50 & 4.71 & 4.88 & 5.02 & 5.11 \\
\hline & & $\varepsilon, \mathrm{mm}$ & 0.0390 & 0.0364 & 0.0349 & 0.0336 & 0.0326 & 0.0320 \\
\hline & \multirow{2}{*}{\begin{tabular}{|c|} 
software \\
package Lira
\end{tabular}} & $\delta_{a s, \text { red }}, \mathrm{mm}$ & 4.19 & 4.32 & 4.41 & 4.49 & 4.55 & 4.61 \\
\hline & & $\varepsilon, \mathrm{mm}$ & 0.0393 & 0.0381 & 0.0372 & 0.0365 & 0.036 & 0.0356 \\
\hline & \multicolumn{2}{|c|}{ discrepancy, \% } & 0.7 & 4.17 & 6.71 & 8.64 & 10.24 & 11.04 \\
\hline 610 & formula 8 & $\delta_{\text {as,red }}, \mathrm{mm}$ & 5.03 & 5.23 & 5.48 & 5.69 & 5.86 & 5.99 \\
\hline & & $\varepsilon, \mathrm{mm}$ & 0.0325 & 0.0313 & 0.0299 & 0.0288 & 0.0280 & 0.0273 \\
\hline & software & $\delta_{\text {as,red }}, \mathrm{mm}$ & 5.81 & 5.85 & 5.94 & 5.98 & 6.0 & 6.03 \\
\hline & ge Lira & $\varepsilon, \mathrm{mm}$ & 0.0282 & 0.0278 & 0.0276 & 0.0274 & 0.0273 & 0.0272 \\
\hline & discrep & ancy, \% & 15.5 & 11.94 & 8.38 & 5.02 & 2.32 & 0.6 \\
\hline
\end{tabular}

The results of the computation are provided in table 2 and the diagrams of the dependence of the reduced mesh thickness and the longitudinal movement of a steel case strip (Fig. 4, Fig. 5, Fig. 6). The strip dimensions have the same number of cells in longitudinal and lateral directions as the new type casing when determining its optimum parameters [8]. 


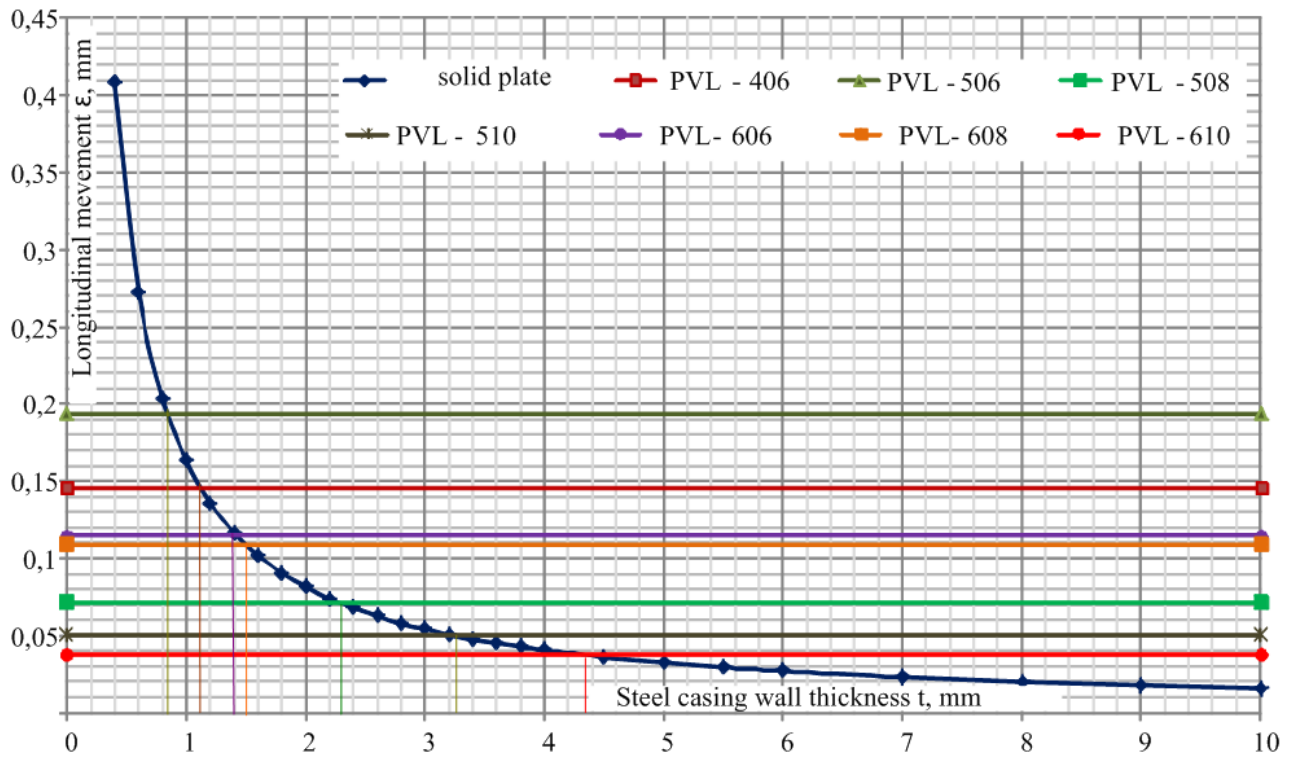

Fig. 4. Determination of the reduced thickness of the expanded metal mesh without concrete wedges.

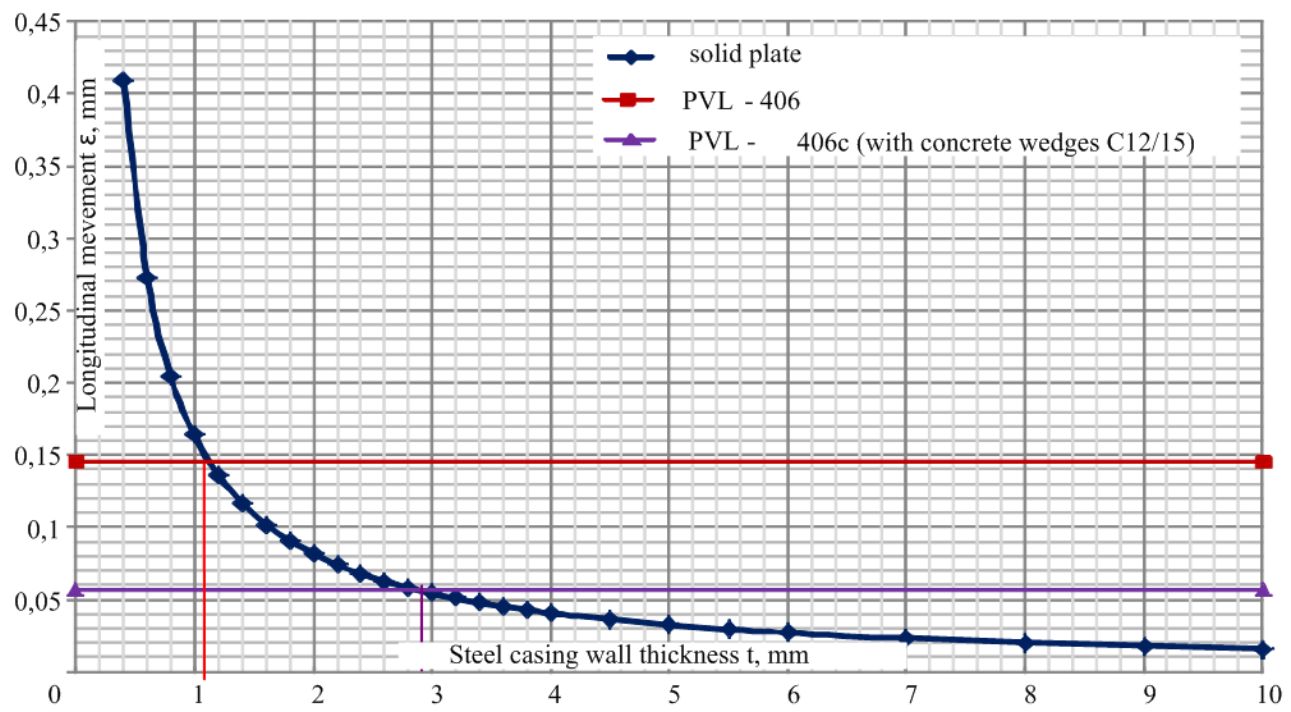

Fig. 5. Impact of concrete wedges in the cells of the expanded metal mesh upon the reduced thickness of the new type casing.

\section{Conclusions}

Thus, the diagrams (Fig. 6-8) enable us to determine the reduced thickness of the steel casing using a graphical method. The comparison of the theoretical and graphical calculations, which are provided in Table 2 , shows that the discrepancies between them are $0.6-15.5 \%$. It testifies that the formula is valid. 


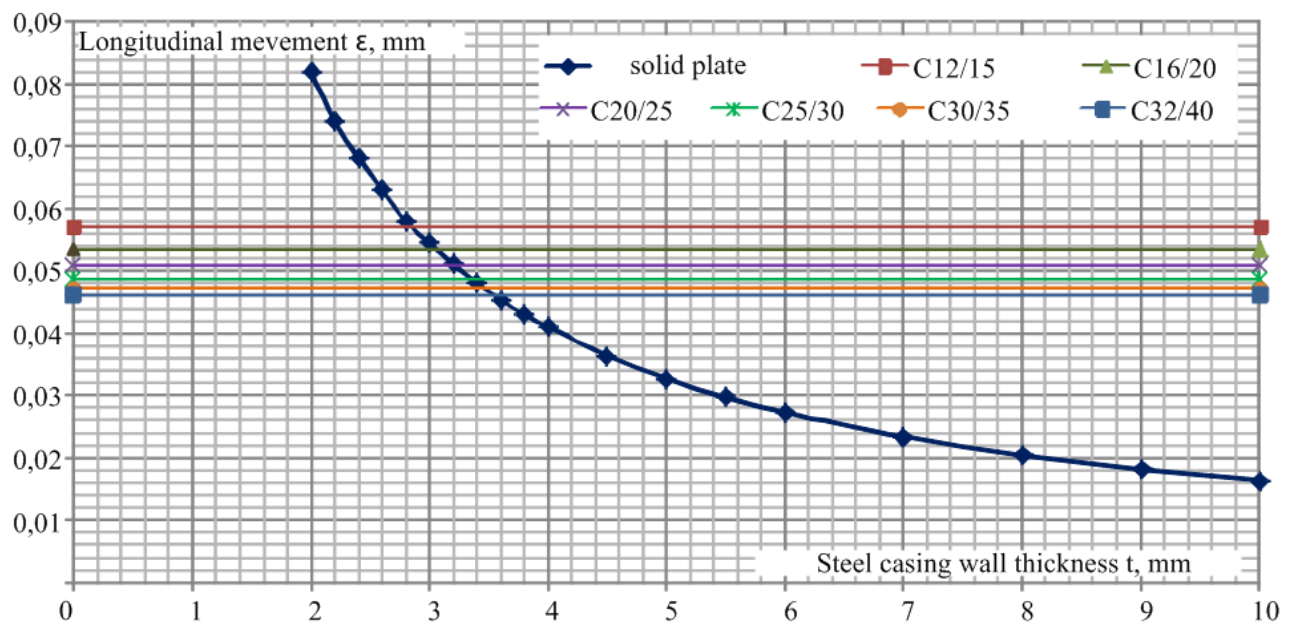

Fig. 6. Change of the reduced thickness of the casing depending on the type of the concrete to fill cells.

\section{References}

1. P.M.Salamahin, L.V.Makovskiy, V.I. Popov i dr., Inzhenernye sooruzhenia $v$ transportnom stroitelstve, Moskva, (2007)

2. Design of concrete structures - Part 1: General Rules and Rules for Building. EN 1992-1: 2001. Eurocode 2, Brussels, (2002)

3. Listy stalnye prosechno-vytiazhnye. Tehnicheskie uslovia. GOST 8706-78, Moskva, (1978)

4. E.V. Sinkovskaya, Naukovyi visnyk budivnyctva, Kharkov, 68, 96-100 (2012)

5. V.S. Shmukler, Yu.A. Klimov, N.P. Burak, Karkasnye sistemy oblegchennogo tipa Kharkov, (2008)

6. V.S. Shmukler, E.A. Petrova, E.V. Sinkovskaya, Naukovyi visnyk budivnyctva, Kharkov, 74, 148-156 (2013)

7. N.A. Alfutov, P.A. Zinovev, B.G. Popov, Rascet mnogosloinyh plastin i obolocek iz kompozitnyh materialov, Moskva, (1984)

8. E.V. Sinkovskaya, E.A. Surzhan, Zbirnyk naukovyh prac Ukrainskoi derzhavnoi akademii zaliznychnogo transport, Kharkov, 149, 169-178 (2014)

9. V.I. Feodocev, Izbrannye zadaci $i$ voprosy po soprotivleniu materialov Moskva, (1967) 